HETEROCYCLES, Vol. , No. , , pp. -. (C) The Japan Institute of Heterocyclic Chemistry

\title{
HIGHLY CONVERGENT STRAIGHTFORWARD STEREOSELECTIVE SYNTHESIS OF (+)-C(9a)-EPIEPIQUINAMIDE
}

\section{Meriem Benlahrech, ${ }^{\text {a }}$ Alejandro Lahosa, ${ }^{\text {b,c,d }}$ Cherif Behloul, ${ }^{\mathrm{a}, *}$ Francisco Foubelo, ${ }^{\mathrm{b}, \mathrm{c}, \mathrm{d}, *}$ and Miguel Yus ${ }^{\mathrm{b}, \mathrm{d}, *}$}

${ }^{a}$ Laboratoire des Produits Naturels d'Origine Végétale et de Synthèse Organique, Université des Frères Mentouri-Constantine, 25000, Algeria

b Departamento de Química Orgánica, Facultad de Ciencias, Universidad de Alicante, Apdo. 9903080 Alicante, Spain

${ }^{\mathrm{c}}$ Instituto de Síntesis Orgánica, Universidad de Alicante, Apdo. 99, 03080 Alicante, Spain

${ }^{\mathrm{d}}$ Centro de Innovación en Química Avanzada (ORFEO-CINQA), Universidad de Alicante, Apdo. 99, 03080 Alicante, Spain

\begin{abstract}
The total synthesis of $(+)-C(9 a)$-epiepiquinamide has been achieved starting from ethyl 5-bromopentanoate, $\left(R_{\mathrm{S}}\right)$-tert-butanesulfinamide, nitromethane, ethyl acrylate and acetic anhydride. The diastereoselective coupling of ethyl 4-nitrobutanoate and a chiral $N$-tert-butanesulfinyl imine, along with a double cyclization involving a primary amine through an intramolecular $N$-alkylation and lactam formation, are key steps of this synthesis.
\end{abstract}

\section{INTRODUCTION}

Alkaloids with the quinolizidine structural motif were isolated from different plants and, in a lesser extension, from animal sources too. ${ }^{1}$ Quinolizidine alkaloids are abundant in the family Leguminosae, especially in the genus Lupinus, ${ }^{2}$ and are biosynthesized through the cyclization of a unit of cadaverine, which derives from aminoacid L-lysine upon decarboxylation. ${ }^{3}$ These natural products exhibit broad pharmacological actions, performing as antipyretics, antibiotics and antivirals. ${ }^{4}$ They function as chemical defense compounds in plants against pathogens and herbivorous animals. ${ }^{5}$ For instance, (-)-lupidine (1) exhibits immunostimulatory activity ${ }^{6}$ and inhibit also cholisnesterases (Figure 1). The tetracyclic bis-

This paper is dedicated to Professor Kiyoshi Tomioka on occasion of his $70^{\text {th }}$ birthday. 
quinolizidine (-)-sparteine (2) is an antiarrhythmic agent ${ }^{7}$ and has also found wide application in asymmetric synthesis as a chiral ligand involving organolithium compounds (Figure 1). ${ }^{8}$ A mixture of quinolizidine alkaloids, among them (+)-sophoridine (3), were present in Sophora flavescens root, which is used in traditional Chinese medicine as antipyretic and diuretic agent (Figure 1). ${ }^{9}$ On the other hand, $(+)$-epiquinamide (4) is a quinolizidine alkaloid which was isolated from the skin of Ecuadoran frog Epipedobates tricolor in 2003. ${ }^{10}$ Primary studies regarding its biological activity indicated that this compound displayed potent and selective activities against nicotinic acetylcholine receptors. However, further more carefully undertaken studies shown that (+)-epiquinamide (4) was inactive and (-)-epibatidine alkaloid (5), ${ }^{11}$ which was isolated also from the same source, was responsible for the biological activity due to contamination in the first studies (Fibure 1). ${ }^{12}$<smiles>OC[C@H]1CCCN2CCCC[C@H]12</smiles>

(-)-lupinine (1)

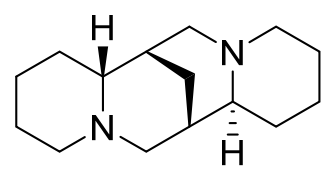

(-)-sparteine (2)

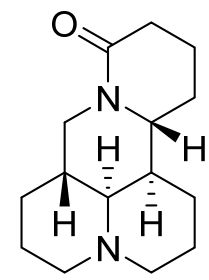

(+)-sophorine (3)

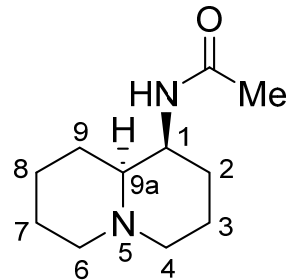

(-)-epiquinamide (4)

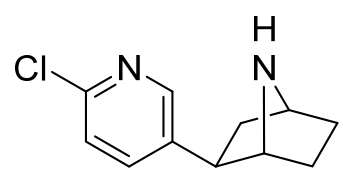

(-)-epibatidine (5)

Figure 1.

In spite of these results, the synthesis of (+)-epiquinamide (4) and its stereoisomers has attracted much attention because these compounds could display potential farmacological activity. ${ }^{13}$ Different synthetic approaches have been reported to access epiquinamide in an enantioselective or racemic ${ }^{12,14}$ fashion. Most of the enantioselective syntheses are based on the chiral pool approach starting from aminoacids ${ }^{15}$ or monosacharides, ${ }^{16}$ and also by means of chiral auxiliaries. ${ }^{17}$ There are also examples where at one step of the synthesis either a resolution of a racemate (enzymatic ${ }^{18 a}$ or with a chiral reagent ${ }^{18 b}$ ) or a catalytic enantioselective procedure is involved. ${ }^{19}$ Continuing our interest in the use of $\mathrm{N}$-tert-butanesulfinyl imines $^{20}$ as electrophiles, and being aware of the potential interest of epiquinamide stereoisomers with regard to biological activity, we decided to explore new synthetic pathways to access to $(+)$-C(9a)-epiepiquinamide (6) in an enantioenriched form, based on the diastereoselective aza-Henry reaction of ethyl 4-nitrobutanoate and a chiral $\mathrm{N}$-tert-butanesulfinyl imine. Our retrosynthentic analysis for the preparation of $(+)-C(9 a)$-epiepiquinamide (6) is depicted on Scheme 1. 


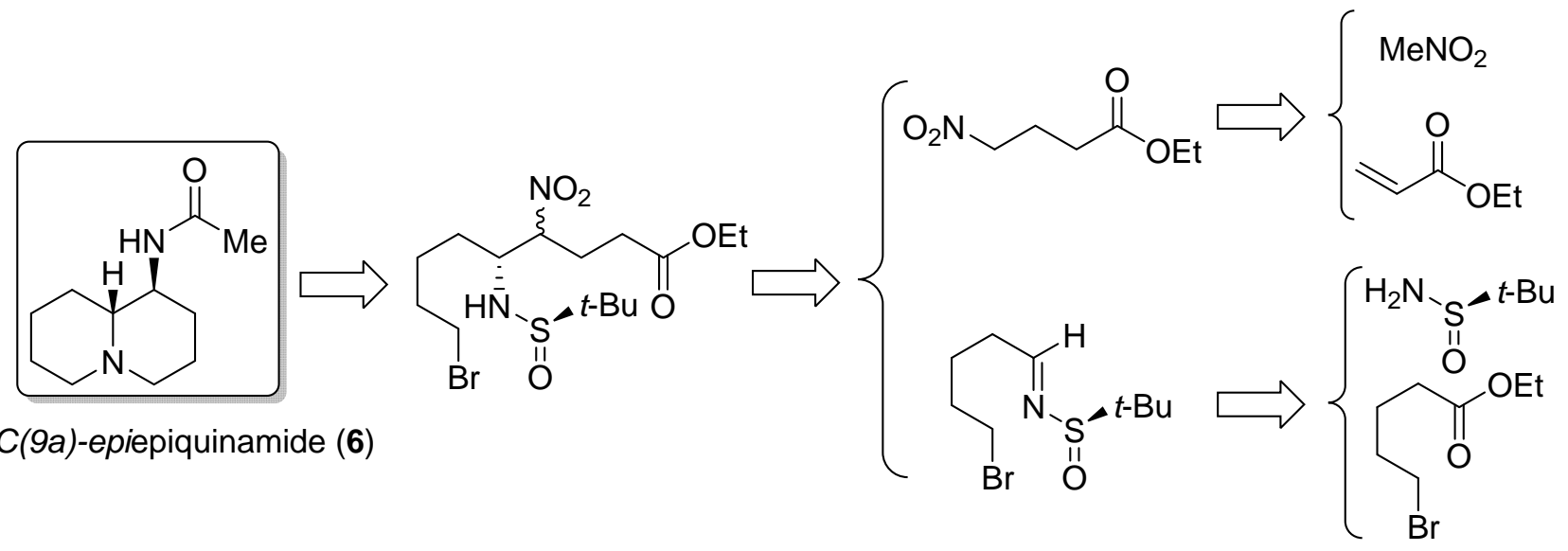

Scheme 1.

\section{RESULTS AND DISCUSSION}

The first building block of this convergent strategy was prepared from ethyl acrylate (7) and nitromethane (8), working under basic conditions. When the reaction was performed in the presence of 0.1 equivalents of sodium hydroxide at 0 to $23{ }^{\circ} \mathrm{C}$ for 12 hours, the expected ethyl 4-nitrobutanoate (9) was obtained in $47 \%$ yield (Method A, Scheme 2). ${ }^{20 t}$ Almost the same yield was reached working under the same reaction conditions but using a $2 \mathrm{M}$ solution of sodium ethoxide in ethanol as a base (Method B, Scheme 2). The second method looks more interesting for scaling up the process. In addition, diethyl 4-nitroheptanedioate (10) was always formed as a side reaction product in yields ranging from 18 to $24 \%$, which results from a double conjugate addition of one molecule of nitromethane (8) to the $\alpha, \beta$-unsaturated ester 7 , in spite of working with a large excess of nitromethane (5 equivalents). Importantly, no additional solvent, apart from the reagents, was needed in this transformation (Scheme 2).

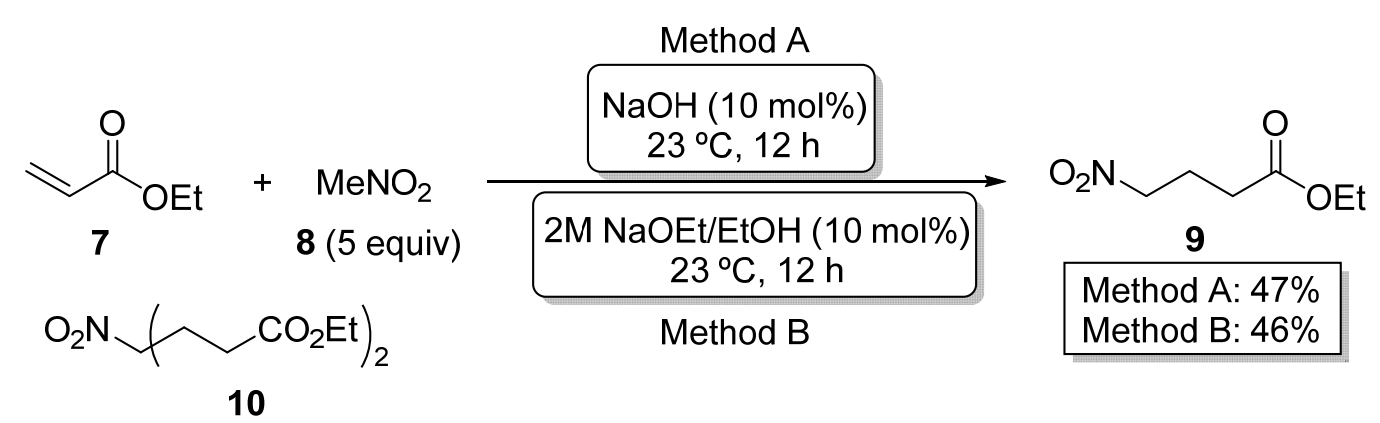

Scheme 2.

The second building block was prepared starting from commercially available ethyl 5-bromopentanoate (11). Reduction of the ester 11 with DIBAL-H in dichloromethane at $-78{ }^{\circ} \mathrm{C}$ for 3 hours led to 5-bromopentanal (12), ${ }^{21}$ which was condensed with $\left(R_{\mathrm{S}}\right)$-tert-butanesulfinamide $(\mathbf{1 3})$ in the presence of titanium tetraethoxide at room temperature for 12 hours, to give the expected $N$-tert-butanesulfinamide 14 
in 54\% overall yield (Scheme 3).<smiles>CCOC(=O)CCCCBr</smiles>

11

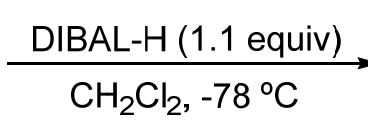

$\mathrm{CH}_{2} \mathrm{Cl}_{2},-78^{\circ} \mathrm{C}$<smiles>O=CCCCCBr</smiles>

12

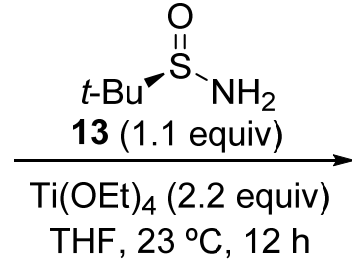

Scheme 3.

The key step of this synthesis is the diastereoselective coupling of nitro ester $\mathbf{9}$ and chiral sulfinyl imine 14. We previously reported the aza-Henry reaction of ethyl 4-nitrobutanoate (9) with chiral $N$-tert-butanesulfinyl imines. Compound 15 was obtained in moderate yields working with 3 equivalents of the nitro ester 9 in the presence of 0.2 equivalents of sodium hydroxide as a base, at $40{ }^{\circ} \mathrm{C}$ for 24 hours. ${ }^{20 t}$ Higher yield was obtained when 0.2 equivalents of a $2 \mathrm{M}$ solution of sodium ethoxide in ethanol was used at $60{ }^{\circ} \mathrm{C}$ for 24 hours (Scheme 4). Fortunately, yield was considerably improved when 0.1 equivalents of sodium ethoxide were added to the reaction mixture first, and after 3 hours, another 0.1 equivalents of the same base were also added, working at room temperature for 13 additional hours (Scheme 4). These reactions proceeded with almost total facial diastereoselectivity considering the addition to the imine functional group. Regarding the second stereogenic center, the one bearing the nitro group, an almost 1:1 mixture of epimers were always obtained, because a rapid epimerization occurs working under basic conditions, due to the acidic character of the proton on that stereocenter. Concerning the stereochemical pathway of the addition of nitrocompounds to chiral $N$-tert-butanesulfinyl imines, we always found that the attack of the nucleophile occurs predominantly to the Si-face of the imine with $R$ configuration at the sulfur atom of the sulfinyl group. ${ }^{20 r, t}$

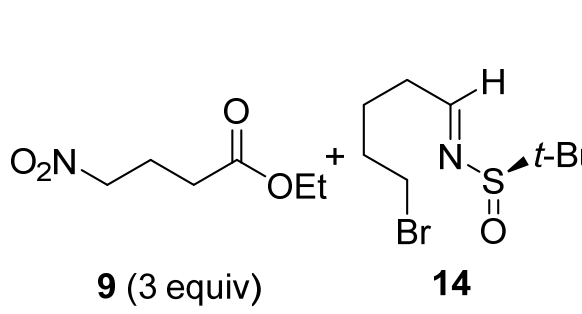

9 (3 equiv)

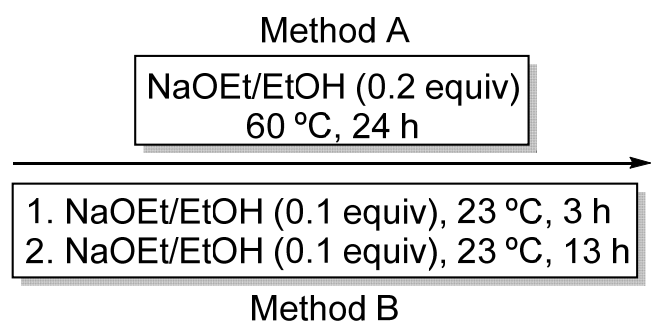

Method B

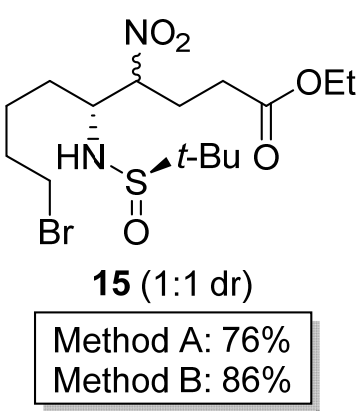

\section{Scheme 4.}

Construction of the quinozinile system was envisioned as arising from a double cyclization involving the 
amine group resulting upon desulfinylation of compound 15. Removal of the tert-butane sulfinyl group was easily achieved by treatment with a $2 \mathrm{M}$ solution of hydrogen chloride in diethyl ether, in ethanol as solvent, and it was completed after 1 hour. Further treatment of the resulting ammonium salt with sodium ethoxide in ethanol at $40{ }^{\circ} \mathrm{C}$ for 20 hours, led to the formation of nitroquinilizidone $\mathbf{1 6}$ in $75 \%$ overall yield (Scheme 5). In this double cyclization, the free amine participated in an intramolecular $N$-alkylation involving the $\mathrm{C}-\mathrm{Br}$ bond and lactam formation with the ester group. Importantly, quinolizidine derivative 16 was formed as 6:1 mixture of diastereoisomers, although compound $\mathbf{1 5}$ was isolated in a 1:1 dr. This experimental result can be explained because epimerization occurs rapidly under basic conditions, and isomer 16 with a trans-fused quinolizidine core in a chair-chair conformation, with the nitro group in an equatorial orientation, is thermodynamically more stable than isomer $\mathbf{1 6}$ '.<smiles>CCOC(=O)CC[C@H](NS(=O)[18OH])[C@H](CCCCBr)[N+](=O)[O-]</smiles>

1. $2 \mathrm{M} \mathrm{HCl} / \mathrm{Et}_{2} \mathrm{O}$ (10 equiv) $\mathrm{EtOH}, 0$ to $23^{\circ} \mathrm{C}, 1 \mathrm{~h}$

2. $2 \mathrm{M} \mathrm{NaOEt} / \mathrm{EtOH}$ (1.5 equiv) $\mathrm{EtOH}, 40^{\circ} \mathrm{C}, 20 \mathrm{~h}$

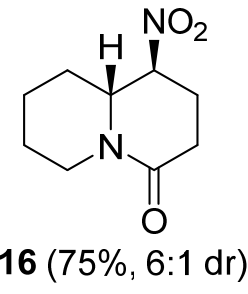

$16(75 \%, 6: 1 d r)$

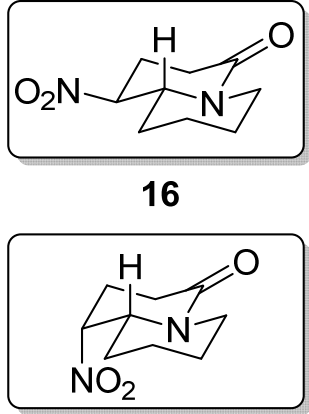

16'

\section{Scheme 5.}

Last steps of the synthesis comprise the reduction of the nitro group to the amino group, the reduction of the lactam to give a bridge trialkyl amine derivative, and final acetylation of the primary amine. Reduction of nitro group in compound $\mathbf{1 6}$ was achieved in almost quantitative yield with hydrogen (1 atm) and Raney-nickel in ethanol at room temperature for 40 hours. Primary amine derivative 17 was isolated in 94\% yield (Scheme 6). Reduction of lactam 17 with lithium aluminium hydride provide the corresponding aminoquinolizidine, which was further $\mathrm{N}$-acetylated to provide the expected (+)-C(9a)-epiepiquinamide (6) in 67\% yield (Scheme 6).<smiles>O=C1CC[C@H]([N+](=O)[O-])[C@H]2CCCCN12</smiles>

16<smiles>N[C@H]1CCC(=O)N2CCCC[C@H]12</smiles>

$17(94 \%)$
1. $\mathrm{LiAlH}_{4}, \mathrm{THF}, 0^{\circ} \mathrm{C}(3 \mathrm{~h})$

and $23^{\circ} \mathrm{C}(1 \mathrm{~h})$

2. $\mathrm{Ac}_{2} \mathrm{O}, \mathrm{NaOH} / \mathrm{H}_{2} \mathrm{O}$, dioxane, $23^{\circ} \mathrm{C}, 12 \mathrm{~h}$

$\mathrm{EtOH}, 23^{\circ} \mathrm{C}, 40 \mathrm{~h}$

Scheme 6.

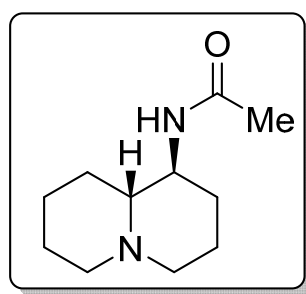

$6(67 \%)$ 
In summary, a straightforward enantioenriched synthesis of (+)-C(9a)-epiepiquinamide (6) was carried out in six synthetic operations starting from commercially available compounds. A diastereoselective aza-Henry reaction of ethyl 4-nitrobutanoate and a chiral $N$-tert-butanesulfinyl imine is the key step of the synthesis, the configuration of the sulfur atom of the sulfinyl group determining the configuration of $\mathrm{C}(9 \mathrm{a})$ stereocenter in this transformation. Target $(+)-C(9 a)$-epiepiquinamide $(6)$ was obtained in a $18.7 \%$ overall yield, considering the lowest yield of the two equally long linear sequence of this convergent synthesis.

\section{EXPERIMENTAL}

All chemicals were commercially available (Acros, Aldrich). TLC was performed on Merck silica gel 60 $\mathrm{F}_{254}$, using aluminum plates and visualized with phosphomolybdic acid (PMA) stain. Chromatographic purification was performed by flash chromatography using Merck silica gel 60 (0.040-0.063 mm) and different eluents. Low-resolution electron impact (EI) mass spectra were obtained at $70 \mathrm{eV}$ on Agilent GC/MS-5973N apparatus equipped with a HP-5MS column (Agilent technologies, $30 \mathrm{~m} \times 0.25 \mathrm{~mm}$ ) and high resolution mass spectra (HRMS-ESI) were obtained on a Waters LCT Premier XE apparatus equipped with a time of flight (TOF) analyzer and the samples were ionized by ESI techniques and introduced through an ultra-high pressure liquid chromatograph (UPLC) model Waters ACQUITY H CLASS. IR spectra were measured (film) with a Nicolet Impact 510 P-FT Spectrometer. NMR spectra were recorded with a Bruker $\mathrm{AC}-300$ and a Bruker 500-AVANCE IIIHD, using $\mathrm{CDCl}_{3}$ or $\mathrm{CD}_{3} \mathrm{OD}$ as solvents, and TMS as internal standard. Optical rotations were measured on a Perkin Elmer 341 polarimeter.

\section{Synthesis of ethyl 4-nitrobutanoate (9) and diethyl 4-nitroheptanedioate (10)}

To a solution of ethyl acrylate $(7)(1.00 \mathrm{~g}, 1.09 \mathrm{~mL}, 10.0 \mathrm{mmol})$ in nitromethane $(3.052 \mathrm{~g}, 2.76 \mathrm{~mL}, 50.0$ mmol) was added a $2 \mathrm{M}$ solution of $\mathrm{NaOEt}$ in $\mathrm{EtOH}(0.50 \mathrm{~mL}, 1.0 \mathrm{mmol})$ at $0{ }^{\circ} \mathrm{C}$. The reaction mixture was stirred for $12 \mathrm{~h}$ and the system was allowed to reach room temperature. Then, the resulting mixture was hydrolyzed with $\mathrm{H}_{2} \mathrm{O}(20 \mathrm{~mL})$ and extracted with EtOAc $(3 \times 15 \mathrm{~mL})$. The organic layer was washed with brine $(2 \times 10 \mathrm{~mL})$, dried over anhydrous MgSO4 and evaporated (15 Torr). The resulting residue was purified by distillation under vacuum to give pure compound $9(0.676 \mathrm{~g}, 4.60 \mathrm{mmol}, 46 \%)$ and the undistilled residue was passed through a path of silica gel with hexane to give pure compound $10(0.548$, $2.10 \mathrm{mmol}, 21 \%$ ). Physical and spectroscopic data follow.

Ethyl 4-nitrobutanonate (9) ${ }^{22}$.- Colourless oil; bp 156-158 ${ }^{\circ} \mathrm{C}$ (20 Torr); $R_{\mathrm{f}} 0.46$ (hexane/EtOAc: $3 / 1$ );

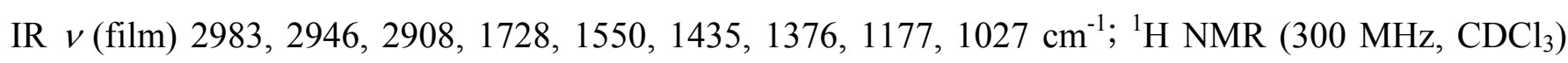


$\delta 4.49(\mathrm{t}, J=6.6 \mathrm{~Hz}, 2 \mathrm{H}), 4.16(\mathrm{q}, J=7.1 \mathrm{~Hz}, 2 \mathrm{H}), 2.47$ (t, $J=6.8 \mathrm{~Hz}, 2 \mathrm{H}), 2.32$ (quint, $J=6.8 \mathrm{~Hz}, 2 \mathrm{H}$ ), $1.27(\mathrm{t}, J=7.1 \mathrm{~Hz}, 3 \mathrm{H}) ;{ }^{13} \mathrm{C} \mathrm{NMR}\left(75 \mathrm{MHz}, \mathrm{CDCl}_{3}\right) \delta 171.8(\mathrm{C}), 74.3,60.9,30.5,22.4\left(\mathrm{CH}_{2}\right), 14.1$ $\left(\mathrm{CH}_{3}\right)$; LRMS (EI) m/z $116\left(\mathrm{M}^{+}-\mathrm{CH}_{3} \mathrm{O}, 35 \%\right), 100$ (9), 88 (11), 69 (10), 59 (100).

Diethyl 4-nitroheptanedioate (10) ${ }^{23}$.- Colourless oil; $R_{\mathrm{f}} 0.44$ (hexane/EtOAc: 3/1); IR $v$ (film) 2983, 2941, 2910, 1729, 1548, 1445, 1375, 1322, 1252, 1182, 1097, $1028 \mathrm{~cm}^{-1} ;{ }^{1} \mathrm{H}$ NMR (300 MHz, $\left.\mathrm{CDCl}_{3}\right)$ $\delta$ 4.70-4.61 (m, 1H), 4.15 (t, $J=7.15 \mathrm{~Hz}, 4 \mathrm{H}), 2.41-2.35(\mathrm{~m}, 4 \mathrm{H}), 2.27-2.12(\mathrm{~m}, 4 \mathrm{H}), 1.26$ (t, $J=7.15 \mathrm{~Hz}$, $6 \mathrm{H}) ;{ }^{13} \mathrm{C}$ NMR $\left(75 \mathrm{MHz}, \mathrm{CDCl}_{3}\right) \delta 171.8(\mathrm{C}), 86.7(\mathrm{CH}), 60.9,30.2,28.7\left(\mathrm{CH}_{2}\right), 14.2\left(\mathrm{CH}_{3}\right)$; LRMS (EI) m/z $216\left(\mathrm{M}^{+}-\mathrm{C}_{2} \mathrm{H}_{5} \mathrm{O}, 26 \%\right), 185$ (10), 170 (51), 169 (62), 157 (22), 141 (97), 123 (100), 113 (52), 111 (28), 99 (48), 95 (50), 85 (15), 71 (81), 67 (42), 60 (16), 55 (63); HRMS (ESI): Calculated for $\mathrm{C}_{9} \mathrm{H}_{14} \mathrm{NO}_{5}$ $\left(\mathrm{M}^{+}-\mathrm{C}_{2} \mathrm{H}_{5} \mathrm{O}\right) 216.0872$, found 216.0879 .

\section{Synthesis of chiral imine 14 from ethyl 5-bromopentanoate (11) and (R)-tert-butanesulfinamide (13)}

To a solution of ethyl 5-bromopentanoate (11) $(1.045 \mathrm{~g}, 0.817 \mathrm{~mL}, 5.0 \mathrm{mmol})$ in dry $\mathrm{CH}_{2} \mathrm{Cl}_{2}(9.0 \mathrm{~mL})$ was added a solution of DIBAL-H in toluene $(4.60 \mathrm{~mL}, 5.5 \mathrm{mmol})$ at $-78^{\circ} \mathrm{C}$. The mixture was stirred for $3 \mathrm{~h}$ at the same temperature, quenched with $1 \mathrm{M} \mathrm{HCl}(5.0 \mathrm{~mL})$ and allowed to reach room temperature. Then, the resulting mixture was hydrolyzed with $\mathrm{H}_{2} \mathrm{O}(15 \mathrm{~mL})$ and extracted with $\mathrm{CH}_{2} \mathrm{Cl}_{2}(3 \times 15 \mathrm{~mL})$. The organic layer was washed with a saturated aqueous solution of $\mathrm{NaHCO}_{3}(2 \times 10 \mathrm{~mL})$, dried over anhydrous MgSO4 and evaporated (15 Torr). The resulting residue was 5-bromopentanal (12) (0.529 g, $3.2 \mathrm{mmol}$ ) and it was pure enough to be used in the next reaction step. Thus, a mixture of (R)-tert-butanesulfinamide (13) (0.428 g, $3.5 \mathrm{mmol})$, 5-bromopentanal (12) (0.529 g, $3.2 \mathrm{mmol})$, and $\mathrm{Ti}(\mathrm{OEt})_{4}(1.596 \mathrm{~g}, 1.465 \mathrm{~mL}, 7.0 \mathrm{mmol})$ in THF $(5.0 \mathrm{~mL})$ was stirred for $12 \mathrm{~h}$ at room temperature. Then, the resulting mixture was hydrolyzed with brine $(8 \mathrm{~mL})$, extracted with EtOAc $(3 \times 10 \mathrm{~mL})$, dried over anhydrous $\mathrm{MgSO}_{4}$ and evaporated (15 Torr). The residue was purified by column chromatography (silica gel, hexane/EtOAc) to yield pure product 14 (0.713 g, $2.66 \mathrm{mmol}, 54 \%$ overall yield). Physical and spectroscopic data follow.

$\left(\boldsymbol{R}_{\mathrm{S}}\right)-\boldsymbol{N}$-(tert-Butanesulfinyl)-5-bromopentan-1-imine (14) $)^{20 \mathrm{y}}$.- Yellow oil; $[\alpha]_{\mathrm{D}}^{20}-171.3$ (c 1.01, $\mathrm{CH}_{2} \mathrm{Cl}_{2}$ ); $R_{\mathrm{f}} 0.32$ (hexane/EtOAc: 3/1); IR $v$ (film) 2956, 1622, 1456, 1362, 1252, 1230, 1183, 1082, 732, $644 \mathrm{~cm}^{-1} ;{ }^{1} \mathrm{H}$ NMR $\left(300 \mathrm{MHz}, \mathrm{CDCl}_{3}\right) \delta 8.08(\mathrm{t}, J=4.4 \mathrm{~Hz}, 1 \mathrm{H}), 3.44(\mathrm{t}, J=6.5 \mathrm{~Hz}, 2 \mathrm{H}), 2.57(\mathrm{td}, J=7.2$, $4.4 \mathrm{~Hz}, 2 \mathrm{H}), 2.03-1.85(\mathrm{~m}, 2 \mathrm{H}), 1.90-1.73(\mathrm{~m}, 2 \mathrm{H}), 1.20(\mathrm{~s}, 9 \mathrm{H}) ;{ }^{13} \mathrm{C} \mathrm{NMR}\left(75 \mathrm{MHz}, \mathrm{CDCl}_{3}\right) \delta 168.8(\mathrm{CH})$, $56.7(\mathrm{C}), 35.2\left(\mathrm{CH}_{2}\right), 33.1\left(\mathrm{CH}_{2}\right), 32.1\left(\mathrm{CH}_{2}\right), 24.0\left(\mathrm{CH}_{2}\right), 22.45\left(\mathrm{CH}_{3}\right)$; LRMS (EI) m/z $213\left(\mathrm{M}^{+}-\mathrm{C}_{4} \mathrm{H}_{8}\right.$, 17\%), $211\left(\mathrm{M}^{+}, 17\right), 84(8), 70(8), 57$ (100), 55 (9), 43 (41), 41 (26). 
To a mixture of ethyl 4-nitrobutanoate $(9)(1.450 \mathrm{~g}, 9.0 \mathrm{mmol})$, and chiral imine 14 (0.805 g, $3.0 \mathrm{mmol})$ was added a $2 \mathrm{M}$ solution of $\mathrm{NaOEt}$ in $\mathrm{EtOH}(0.15 \mathrm{~mL}, 0.2 \mathrm{mmol})$ at room temperature and was stirred for $3 \mathrm{~h}$. Then a $2 \mathrm{M}$ solution of $\mathrm{NaOEt}$ in $\mathrm{EtOH}(0.15 \mathrm{~mL}, 0.2 \mathrm{mmol})$ was also added and the resulting reaction mixture was stirred at the same temperature for 13 additional $\mathrm{h}$. The resulting mixture was hydrolyzed with $\mathrm{H}_{2} \mathrm{O}(15 \mathrm{~mL})$ and extracted with EtOAc $(3 \times 15 \mathrm{~mL})$. The organic layer was washed with brine $(2 \times 10 \mathrm{~mL})$, dried over anhydrous $\mathrm{MgSO} 4$, and evaporated (15 Torr). The residue was purified by column chromatography (silica gel, hexane/EtOAc) to yield pure compound 15 (1.100 g, 2.57 mmol, 86\%). Physical and spectroscopic data follow.

$\left(4 R^{*}, 5 R, R_{\mathrm{S}}\right)$-Ethyl 9-bromo- $N$-(tert-butanesulfinyl)-5-amino-4-nitrononanoate (15).- Mixture of diastereoisomers (1:1); colourless oil; $R_{\mathrm{f}} 0.47$ (hexane/EtOAc: 1/1); IR $v$ (film) 3421, 3230, 2960, 2869, 1732, 1625, 1549, 1457, 1367, 1303, 1184, 1055, $911 \mathrm{~cm}^{-1} ;{ }^{1} \mathrm{H}$ NMR $\left(300 \mathrm{MHz}, \mathrm{CDCl}_{3}\right) \delta 4.96-4.83(\mathrm{~m}$, 2H), $4.27(\mathrm{~d}, J=8.6 \mathrm{~Hz}, 1 \mathrm{H}), 4.21(\mathrm{~d}, J=9.8 \mathrm{~Hz}, 1 \mathrm{H}), 4.16(\mathrm{q}, J=7.2 \mathrm{~Hz}, 4 \mathrm{H}), 3.62-3.50(\mathrm{~m}, 2 \mathrm{H}), 3.40(\mathrm{t}$, $J=6.4 \mathrm{~Hz}, 4 \mathrm{H}), 2.61-2.14(\mathrm{~m}, 8 \mathrm{H}), 1.97-1.79(\mathrm{~m}, 4 \mathrm{H}), 1.76-1.44(\mathrm{~m}, 8 \mathrm{H}), 1.27(\mathrm{~s}, 9 \mathrm{H}), 1.27(\mathrm{t}, J=7.1 \mathrm{~Hz}$, $6 \mathrm{H}), 1.26(\mathrm{~s}, 9 \mathrm{H}),{ }^{13} \mathrm{C} \mathrm{NMR}\left(75 \mathrm{MHz}, \mathrm{CDCl}_{3}\right) \delta 172.1,172.05(\mathrm{C}), 90.8,89.8(\mathrm{CH}), 61.0,61.0\left(\mathrm{CH}_{2}\right), 59.4$, $58.5(\mathrm{CH}), 56.9,56.8(\mathrm{C}), 33.35,33.3,32.8,32.05,32.0,30.6,30.15,29.9,26.0,25.2,24.6,24.5\left(\mathrm{CH}_{2}\right)$, 22.9, 22.8, 14.2 , $14.2\left(\mathrm{CH}_{3}\right)$; LRMS (EI) m/z $385\left(\mathrm{M}^{+}-\mathrm{C}_{2} \mathrm{H}_{5} \mathrm{O}, 2 \%\right), 383$ (2\%), 232 (10), 230 (8), 213 (8), 162 (14), 116 (27), 93 (8), 67 (9), 57 (100), 55 (16), 41 (26); HRMS (ESI): Calculated for $\mathrm{C}_{15} \mathrm{H}_{28}{ }^{79} \mathrm{BrN}_{2} \mathrm{O}_{5} \mathrm{~S}\left(\mathrm{M}^{+}\right)$427.0902, found 427.0905.

\section{Synthesis of nitroquinolizidinone 16 from compound 15 through an intramolecular double cyclization}

To a solution of compound $15(0.601 \mathrm{~g}, 1.40 \mathrm{mmol})$ in EtOH $(15 \mathrm{~mL})$ was added a $2 \mathrm{M}$ solution of $\mathrm{HCl}$ in in $\mathrm{Et}_{2} \mathrm{O}(7.0 \mathrm{~mL}, 14.0 \mathrm{mmol})$ at $0{ }^{\circ} \mathrm{C}$. The reaction mixture was allowed to reach room temperature and stirred for $1 \mathrm{~h}$. After that all volatiles were removed under vacuum (15 Torr) and the resulting residue was dissolved in EtOH $(100 \mathrm{~mL})$. A $2 \mathrm{M}$ solution of $\mathrm{NaOEt}$ in EtOH $(1.05 \mathrm{~mL}, 2.1 \mathrm{mmol})$ was added to this ethanolic solution, and the reaction mixture was stirred at $40{ }^{\circ} \mathrm{C}$ for $20 \mathrm{~h}$. Then, EtOH was removed under vacuum (15 Torr), and the resulting residue was hydrolyzed with a saturated aqueous solution of $\mathrm{NaHCO}_{3}$ $(100 \mathrm{~mL})$, and brine $(15 \mathrm{~mL})$, and extracted with EtOAc $(3 \times 25 \mathrm{~mL})$. The organic layer was dried over anhydrous MgSO4, and evaporated (15 Torr). The residue was purified by column chromatography (silica gel, hexane/EtOAc) to yield pure compound 16 (0.208 g, $1.05 \mathrm{mmol}, 75 \%)$. Physical and spectroscopic data follow.

(4S)-4-Nitrohexahydro-2H-quinolizin-1(6H)-one (16).- Brow-orange liquid; $[\alpha]^{20}+6.3$ (c 1.01, $\left.\mathrm{CH}_{2} \mathrm{Cl}_{2}\right) ; R_{\mathrm{f}} 0.48\left(\mathrm{CH}_{2} \mathrm{Cl}_{2} / \mathrm{MeOH}\right.$ : 18/1); IR $v$ (film) 2941, 2858, 1635, 1547, 1470, 1444, 1421, 1377, 1363, 1343, 1272, 1198, $914 \mathrm{~cm}^{-1} ;{ }^{1} \mathrm{H}$ NMR (300 MHz, $\left.\mathrm{CDCl}_{3}\right) \delta 4.85-4.73(\mathrm{~m}, 1 \mathrm{H}), 4.58-4.50(\mathrm{~m}, 1 \mathrm{H})$, 
4.00 (ddd, $J=11.7,5.1,2.5 \mathrm{~Hz}, 1 \mathrm{H}), 2.59-2.41$ (m, 3H), 2.39-2.27 (m, 2H), 2.03-1.92 (m, 1H), 1.91-1.82 $(\mathrm{m}, 1 \mathrm{H}), 1.78-1.69(\mathrm{~m}, 1 \mathrm{H}), 1.68-1.54(\mathrm{~m}, 1 \mathrm{H}), 1.52-1.35(\mathrm{~m}, 2 \mathrm{H}) ;{ }^{13} \mathrm{C} \mathrm{NMR}\left(75 \mathrm{MHz}, \mathrm{CDCl}_{3}\right) \delta 166.5$ (C), 84.9, $58.3(\mathrm{CH}), 43.2$, 32.0, 28.4, 24.8, 24.3, $23.9\left(\mathrm{CH}_{2}\right)$; LRMS (EI) m/z $198\left(\mathrm{M}^{+}, 1 \%\right), 152$ (20), 151 (100), 150 (17), 136 (25), 123 (12), 122 (27), 108 (16), 97 (12), 82 (12), 67 (12), 55 (27); HRMS (ESI): Calculated for $\mathrm{C}_{9} \mathrm{H}_{14} \mathrm{NO}\left(\mathrm{M}^{+}-\mathrm{NO}_{2}\right)$ 152.1075, found 152.1065 .

\section{Synthesis of aminoquinolizidinone 17 by reduction of nitrocompound 16}

To a solution of nitro compound $16(0.071 \mathrm{~g}, 0.356 \mathrm{mmol})$ in EtOH $(3.0 \mathrm{~mL})$ was added commercially available Raney nickel $(0.812 \mathrm{~g}, 0.3 \mathrm{~mL}, 50 \%$ slurry in water) and the mixture was vigorously stirred at room temperature in hydrogen atmosphere $(1 \mathrm{~atm})$ for $40 \mathrm{~h}$. The resulting suspension was filtered through a short pad of Celite with EtOH $(40 \mathrm{~mL})$ and concentrated in vacuo (15 Torr). The residue was pure compound 17 (0.056 g, $0.333 \mathrm{mmol}, 94 \%)$. Physical and spectroscopic data follow.

(4S)-4-Aminohexahydro-2H-quinolizin-1(6H)-one (17).- Brow-orange oil; $[\alpha]^{20}{ }_{\mathrm{D}}-9.0$ (c 1.06, $\mathrm{CH}_{2} \mathrm{Cl}_{2}$ ); $R_{\mathrm{f}} 0.12\left(\mathrm{CH}_{2} \mathrm{Cl}_{2} / \mathrm{MeOH}: 18 / 1\right)$; IR $v$ (film) 3282, 2931, 2856, 1709, 1621, 1467, 1443, 1421, 1272, 1172 , $837 \mathrm{~cm}^{-1} ;{ }^{1} \mathrm{H}$ NMR $\left(300 \mathrm{MHz}, \mathrm{CDCl}_{3}\right) \delta 4.82-4.69(\mathrm{~m}, 1 \mathrm{H}), 3.04-2.91(\mathrm{~m}, 1 \mathrm{H}), 2.94-2.83(\mathrm{~m}, 1 \mathrm{H})$, 2.62-2.31 (m, 5H), 2.12-1.82 (m, 3H), 1.78-1.61 (m, 2H), 1.56-1.28 (m, 3H); $\left.{ }^{13} \mathrm{C} \mathrm{NMR} \mathrm{(75} \mathrm{MHz,} \mathrm{CDCl}_{3}\right)$ $\delta 168.5(\mathrm{C}), 64.4,51.9(\mathrm{CH}), 42.8,32.0,30.1,28.3,25.15,24.3\left(\mathrm{CH}_{2}\right)$; LRMS (EI) m/z $168\left(\mathrm{M}^{+}, 35 \%\right), 125$ (21\%), 97 (82), 84 (100), 83 (36), 82 (9), 56 (28), 55 (16); HRMS (ESI): Calculated for $\mathrm{C}_{9} \mathrm{H}_{16} \mathrm{~N}_{2} \mathrm{O}\left(\mathrm{M}^{+}\right)$ 168.1263 , found 168.1265 .

\section{Synthesis of $(+)-C(9 a)$-epiepiquinamide (6) from aminoquinolizidinone 17}

To a solution of aminoquinolizidinone $17(0.0747 \mathrm{~g}, 0.44 \mathrm{mmol})$ in dry THF $(10 \mathrm{~mL})$ was added $\mathrm{LiAlH}_{4}$ $(0.0479 \mathrm{~g}, 1.20 \mathrm{mmol})$ at $0{ }^{\circ} \mathrm{C}$. The reaction mixture was stirred at $0{ }^{\circ} \mathrm{C}$ for $3 \mathrm{~h}$, and at room temperature for $1 \mathrm{~h}$. After that, $\mathrm{H}_{2} \mathrm{O}(0.44 \mathrm{~mL}), \mathrm{K}_{2} \mathrm{CO}_{3}(0.44 \mathrm{~g}, 11.5 \mathrm{mmol})$ and $\mathrm{H}_{2} \mathrm{O}(0.44 \mathrm{~mL})$ were successively added. The gray solid was filtered off and washed with EtOAc $(30 \mathrm{~mL})$. The filtrate was concentrated in vacuo (15 Torr) to provide a colourless oil which was then dissolved in dry dioxane $(4.0 \mathrm{~mL})$. A $1 \mathrm{M}$ solution of $\mathrm{NaOH}(4.4 \mathrm{~mL}, 4.4 \mathrm{mmol})$ was added followed by $\mathrm{Ac}_{2} \mathrm{O}(0.225 \mathrm{~g}, 0.212 \mathrm{~mL}, 2.2 \mathrm{mmol})$. The reaction mixture was stirred at room temperature for $12 \mathrm{~h}$. After that, it was hydrolyzed with a saturated aqueous solution of $\mathrm{NaHCO}_{3}(5 \mathrm{~mL})$, and extracted with $\mathrm{CH}_{2} \mathrm{Cl}_{2}(3 \times 10 \mathrm{~mL})$. The organic layer was dried over anhydrous MgSO4, and evaporated (15 Torr). The residue was purified by column chromatography (silica gel, $\left.\mathrm{CH}_{2} \mathrm{Cl}_{2} / \mathrm{MeOH}, 9 / 1\right)$ to yield pure compound 6 (0.058 g, $0.296 \mathrm{mmol}, 67 \%$ ). Physical and spectroscopic data follow.

(+)-C(9a)-Epiepiquinamide (6).- White solid, mp 124-126 ${ }^{\circ} \mathrm{C}$ (hexane $/ \mathrm{CH}_{2} \mathrm{Cl}_{2}$ ); $[\alpha]_{\mathrm{D}}^{20}+2.4(c \quad 0.63$, $\left.\mathrm{CH}_{2} \mathrm{Cl}_{2}\right) ; R_{\mathrm{f}} 0.12\left(\mathrm{CH}_{2} \mathrm{Cl}_{2} / \mathrm{MeOH}: 18 / 1\right)$; IR $v(\mathrm{KBr}) 3280,2929,2853,1639,1557,1444,1372,1310$, 
1122, 1113, $1023 \mathrm{~cm}^{-1} ;{ }^{1} \mathrm{H}$ NMR (500 MHz, CD $\left.\mathrm{OD}\right) \delta 3.68$ (ddd, $\left.J=11.9,9.9,4.3 \mathrm{~Hz}, 1 \mathrm{H}\right), 3.01-2.94(\mathrm{~m}$, $1 \mathrm{H}), 2.93-2.85(\mathrm{~m}, 1 \mathrm{H}), 2.31-2.20(\mathrm{~m}, 2 \mathrm{H}), 1.93(\mathrm{~s}, 3 \mathrm{H}), 1.93-1.90(\mathrm{~m}, 1 \mathrm{H}), 1.90-1.87(\mathrm{~m}, 1 \mathrm{H}), 1.84-1.78$ $(\mathrm{m}, 1 \mathrm{H}), 1.77-1.67(\mathrm{~m}, 3 \mathrm{H}), 1.66-1.57(\mathrm{~m}, 1 \mathrm{H}), 1.41-1.27(\mathrm{~m}, 4 \mathrm{H}), 1.26-1.18(\mathrm{~m}, 1 \mathrm{H}) ;{ }^{13} \mathrm{C} \mathrm{NMR}(126 \mathrm{MHz}$, $\left.\mathrm{CD}_{3} \mathrm{OD}\right) \delta 172.7(\mathrm{C}), 68.0(\mathrm{CH})$, 57.2, $56.6\left(\mathrm{CH}_{2}\right), 51.8(\mathrm{CH}), 32.0,29.4,26.0,24.8,24.4\left(\mathrm{CH}_{2}\right), 22.7$ $\left(\mathrm{CH}_{3}\right)$; LRMS (EI) m/z $138\left(\mathrm{M}^{+}-\mathrm{C}_{2} \mathrm{H}_{4} \mathrm{NO}, 11 \%\right), 137$ (100), 136 (40), 122 (11), 83 (31), 70 (11), 55 (10), 43 (12); HRMS (ESI): Calculated for $\mathrm{C}_{9} \mathrm{H}_{15} \mathrm{~N}\left(\mathrm{M}^{+}-\mathrm{C}_{2} \mathrm{H}_{5} \mathrm{NO}\right)$ 137.1206, found 137.1204.

\section{ACKNOWLEDGEMENTS}

We thank the continued financial support from our Ministerio de Ciencia e Innovación (MCINN; projects CONSOLIDER INGENIO 2010-CDS2007-00006, CTQ2011-24165), the Ministerio de Economía y Competitividad (MINECO; project CTQ2014-53695-P, CTQ2014-51912-REDC el otro, CTQ2017-85093-P), FEDER, the Generalitat Valenciana (PROMETEO 2009/039, PROMETEOII/2014/017) the University of Alicante, the Ministère de l'Enseignement Supérieur et de la Recherche Scientifique Algérienne; Direction de la Coopération et des Echanges Interuniversitaires; Programme de Formation Résidentielle à l'Étranger au titre de l'année universitaire 2016/2017: Programme National Exceptionnel (PNE).

\section{REFERENCES}

1. J. P. Michael, Nat. Prod. Rep., 2005, 22, 603.

2. M. Wink, C. Meissner, and L. Witte, Phytochemistry, 1995, 38, 139.

3. W. M. Golebiewski, and I. D. Spenser, Can. J. Chem., 1988, 66, 1734.

4. S. Bunsupa, M. Yamazaki, and K. Saito, Front. Plant. Sci., 2012, 3, 239.

5. M. Wink, Planta Med., 1987, 53, 509.

6. E. O. Omeje, P. O. Osadebe, C. S. Nworu, J. N. Nwodo, W. O. Obonga, A. Kawamura, C. O. Esimone, and P. Proksch, Pharm Biol., 2011, 49, 1271.

7. J. Senges, and L. Ehe, Naunyn Schmiedebergs Arch. Pharmacol., 1973, 280, 265.

8. (a) D. Hoppe, and T. Hense, Angew. Chem. Int. Ed., 1997, 36, 2282; (b) O. Chuzel, O. Riant, Top. Organomet. Chem., 2005, 15, 59.

9. X. Zhang, Z. Cui, D. Wang, and H.-Y. Zhou, J. Asian Nat. Prod. Res., 2003, 5, 171.

10. R. W. Fitch, H. M. Garraffo, T. F. Spande, H. J. C. Yeh, and J. W. Daly, J. Nat. Prod., 2003, 66, 1345.

11. T. F. Spande, H. M. Garrafo, M. W. Edwards, H. J. C. Yeh, L. Pannell, and J. W. Daly, J. Am. 
Chem. Soc., 1992, 114, 3475.

12. R. W. Fitch, G. D. Sturgeon, S. R. Patel, T. F. Spande, H. M. Garraffo, J. W. Daly, and R. H. Blaauw, J. Nat. Prod., 2009, 72, 243.

13. U. C. Rajesh, A. Gupta, and D. S. Rawat Curr. Org. Synth., 2014, 11, 627.

14. (a) A. Kanakubo, D. Gray, N. Innocent, S. Wonnacott, and T. Gallagher, Bioorg. Med. Chem. Lett., 2006, 16, 4648; (b) N. Kise, K. Fukazawa, and T. Sakurai, Tetrahedron Lett., 2010, 51, 5767.

15. (a) M. A. Wijdeven, P. N. M. Botman, R. Wijtmans, H. E. Schoemaker, F. P. J. T. Rutjes, and R. H. Blaauw, Org. Lett., 2005, 7, 4005; (b) P.-Q. Huang, Z.-Q. Guo, and Y.-P. Ruan, Org. Lett., 2006, 8, 1435; (c) T. L. Suyama, and W. H. Gerwick, Org. Lett., 2006, 8, 4541; (d) A. K. Srivastava, S. K. Das, and G. Panda, Tetrahedron, 2009, 65, 5322; (e) M. Hajri, C. Blondelle, A. Martinez, J.-L. Vasse, and J. Szymoniak, Tetrahedron Lett., 2013, 54, 1029.

16. (a) S. Ghosh, and J. Shashidhar, Tetrahedron Lett., 2009, 50, 1177; (b) W. Sangsuwan, B. Kongkathip, P. Chuawong, and N. Kongkathip, Tetrahedron, 2017, 73, 7274.

17. (a) A. Voituriez, F. Ferreira, A. Pérez-Luna, and F. Chemla, Org. Lett., 2007, 9, 4705; (b) E. Airiau, T. Spangenberg, N. Girard, B. Breit, and A. Mann, Org. Lett., 2010, 12, 528; (c) L. Silva Santos, Y. Mirabal-Gallardo, N. Shankaraiah, and M. J. Simirgiotis, Synthesis, 2011, 51; (d) C.-M. Si, Z.-Y. Mao, H.-Q. Dong, Z.-T. Du, B.-G. Wei, and G.-Q. Lin, J. Org. Chem., 2015, 80, 5824.

18. (a) M. A. Wijdeven, R. Wijtmans, R. J. F. van den Berg, W. Noorduin, H. E. Schoemaker, T. Sonke, F. L. van Delft, R. H. Blaauw, R. W. Fitch, T. F. Spande, J. W. Daly, and F. P. J. T. Rutjes, Org. Lett., 2008, 10, 4001; (b) S. T. Tong, and D. Barker, Tetrahedron Lett., 2006, 47, 5017.

19. (a) S. Chandrasekhar, B. B. Parida, and C. Rambabu, Tetrahedron Lett., 2009, 50, 3294; (b) B. B. Ahuja, L. Emmanuvel, and A. Sudalai, Synlett., 2016, 27, 1699.

20. (a) F. Foubelo and M. Yus, Tetrahedron: Asymmetry, 2004, 15, 3823; (b) J. C. González-Gómez, F. Foubelo, and M. Yus, Synlett, 2008, 2777; (c) M. Medjahdi, J. C. González-Gómez, F. Foubelo, and M. Yus, Heterocycles, 2008, 76, 569; (d) M. Medjahdi, J. C. González-Gómez, F. Foubelo, and M. Yus, J. Org. Chem., 2009, 74, 7859; (e) H. K. Dema, F. Foubelo, and M. Yus, Heterocycles, 2010, 80, 125; (f) J. C. González-Gómez, M. Medjahdi, F. Foubelo, and M. Yus, J. Org. Chem., 2010, 75, 6308; (g) H. K. Dema, F. Foubelo, and M. Yus, Heterocycles, 2011, 82, 1411; (h) M. Medjahdi, J. C. González-Gómez, F. Foubelo, and M. Yus, Eur. J. Org. Chem., 2011, 2230; (i) I. Bosque, J. C. González-Gómez, F. Foubelo, and M. Yus, J. Org. Chem., 2012, 77, 780 (correction: I. Bosque, J. C. González-Gómez, F. Foubelo, and M. Yus, J. Org. Chem., 2012, 77, 4190); (j) I. Bosque, J. C. González-Gómez, A. Guijarro, F. Foubelo, and M. Yus, J. Org. Chem., 2012, 77, 10340; (k) J. A. Sirvent, F. Foubelo, and M. Yus, Chem. Commun. 2012, 48, 2543; (1) H. K. Dema, F. Foubelo, and M. Yus, Helv. Chim. Acta, 2012, 95, 1790; (m) M. Medjahdi, J. C. González-Gómez, F. Foubelo, and 
M. Yus, Heterocycles, 2012, 86, 727; (n) M. J. García-Muñoz, F. Zacconi, F. Foubelo, and M. Yus, Eur. J. Org. Chem., 2013, 1287; (o) J. A. Sirvent, F. Foubelo, and M. Yus, Eur. J. Org. Chem., 2013, 2461; (p) J. A. Sirvent, F. Foubelo, and M. Yus, Heterocycles, 2018, 88, 1163; (q) J. A. Sirvent, F. Foubelo, and M. Yus, J. Org. Chem., 2014, 79, 1356; (r) M. J. García-Muñoz, H. K. Dema, F. Foubelo, and M. Yus, Tetrahedron: Asymmetry, 2014, 25, 362; (s) O. S. R. Barros, J. A. Sirvent, F. Foubelo, and M. Yus, Chem. Commun., 2014, 50, 6898; (t) M. J. García-Muñoz, F. Foubelo, and M. Yus, Heterocycles, 2015, 90, 1419; (u) A. Lahosa, F. Foubelo, and M. Yus, Eur. J. Org. Chem., 2016, 4067; (v) E. Maciá, F. Foubelo, and M. Yus, Tetrahedron, 2016, 72, 6001; (w) M. J. García-Muñoz, F. Foubelo, and M. Yus, J. Org. Chem., 2016, 81, 10214; (x) A. Sirvent, T. Soler, F. Foubelo, and M. Yus, Chem. Commun., 2017, 53, 2701; (y) A. Lahosa, T. Soler, A. Arrieta, F. P. Cossio, F. Foubelo, and M. Yus, J. Org. Chem., 2017, 82, 7481; (z) E. Maciá, F. Foubelo, and M. Yus, Tetrahedron: Asymmetry, 2017, 28, 1407.

21. W. J. Nodes, D. R. Nutt, A. M. Chippindale, and A. J. A. Cobb, J. Am. Chem. Soc., 2009, 131, 16016.

22. B. M. Choudary, M. Lakshmi Kantam, B. Kavita, C. Venkat Reddya, and F. Figueras, Tetrahedron, 2000, 56, 9357.

23. S. Farooq, P. L. Sangwan, R. R. Aleti, P. K. Chinthakindi, M. A. Qurishi, and S. Koul, Tetrahedron Lett., 2012, 53, 3305. 
Please attach the original file

( Chemdraw, Chemwindows, ISIS Draw, etc)

Highly Convergent Straightforward Stereoselective

Synthesis of (+)-C(9a)-Epiepiquinamide

Meriem Benlahrech, Alejandro Lahosa, Cherif

Behloul, ${ }^{*}$ Francisco Foubelo, ${ }^{*}$ and Miguel Yus*

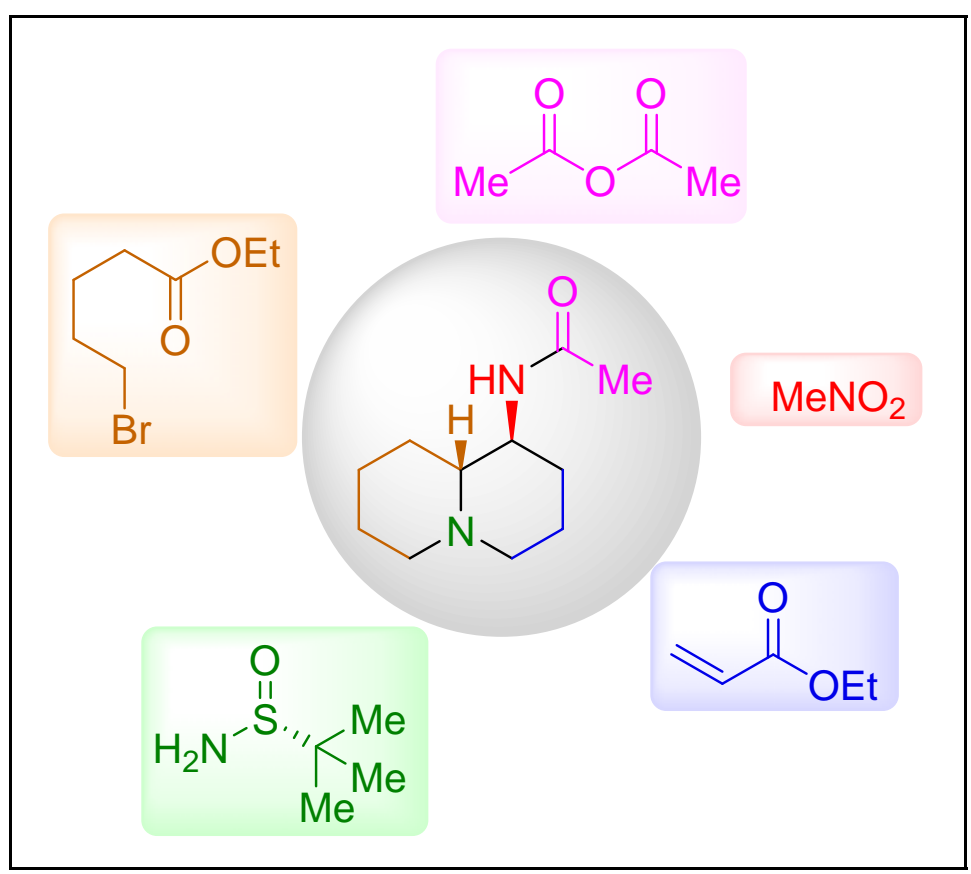

